\title{
Metadata for macrophyte data from the Boro-Xudum seasonal floodplains of the Okavango Delta
}

Michael Murray-Hudson (D), Kaelo Makati, Ineelo Mosie \& Piotr Wolski
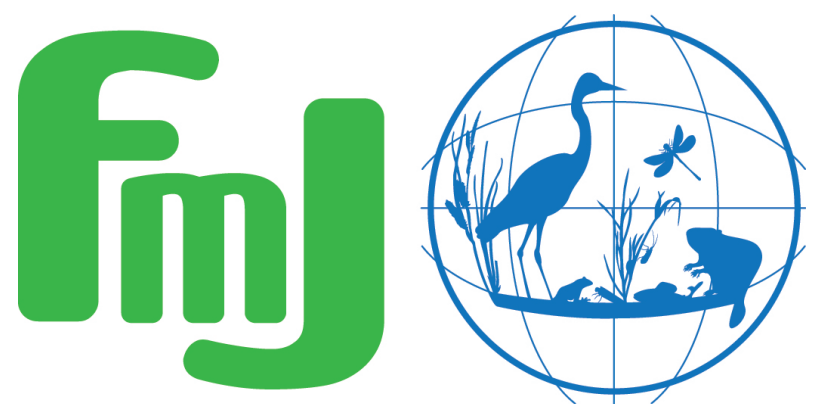

Freshwater Metadata Journal 



\title{
Metadata for macrophyte data from the Boro-Xudum seasonal floodplains of the Okavango Delta
}

\author{
Michael Murray-Hudson ${ }^{1}$ iD , Kaelo Makati ${ }^{1}$, Ineelo Mosie ${ }^{1}$ \& Piotr Wolski ${ }^{2}$ \\ 1 University of Botswana Okavango Research Institute, Maun, Botswana; corresponding author: mmurray-hudson@ub.ac.bw \\ 2 University of Cape Town Climate Systems Analysis Group, Cape Town, South Africa
}

Please cite this paper as follows: Murray-Hudson, M., Makati, K., Mosie, I. \& Wolski, P., 2019. Metadata for macrophyte data from the Boro-Xudum seasonal floodplains of the Okavango Delta. Freshwater Metadata Journal 45: 1-8. https://doi.org/10.15504/fmj.2019.45

Received: 2019-09-03 / Published: 2019-09-30

\section{Keywords}

herbaceous macrophytes, seasonal floodplains, Okavango Delta, hydroperiod, tropical wetlands, flood pulse, occurrence, relative abundance

\section{Short description of the dataset/summary}

This study covered the southern parts of the Okavango Delta - the seasonally flooded Xudum and Boro distributary systems. It was a single campaign aimed at collecting and analysing floodplain vegetation species and abundance data, to establish relationships with hydroperiod for exploratory scenario modelling. A stratified random sample of 30 sites was surveyed for species composition and abundance between mid-March and mid-July 2007, using multiple 1 sq m quadrats along transects orthogonal to the floodplain long axis. Minimum sampled area at each site was $30 \mathrm{sq} \mathrm{m}$. Hydroperiod was established based on three sets of remote sensing data: 1:50,000 analogue aerial photography from 2001, Landsat (annual) and MODIS (monthly) data from 2000-2007, and ground truthing from 2007.

\section{General information}

dataset entry ID:

name of the dataset:

full name of the dataset:

dataset short name:

type of dataset:

data type:

\section{FWM_24}

Seasonal floodplain herbaceous plant species in the Okavango Delta, Botswana Boro and Xudum Floodplain Vegetation Data 2007

species (taxonomic group) per site database including environmental information

point data/observation data

science keywords according to GCMD:

topic:

Biosphere, Terrestrial Hydrosphere 


\section{ISO topic category according to ISO 19115: \\ Biota, Inland Waters}

INSPIRE keywords according to GEMET:

own science keywords:

Habitats and biotopes, Hydrography, Species distribution herbaceous macrophytes, seasonal floodplains, Okavango Delta, hydroperiod, tropical wetlands, flood pulse, occurrence, relative abundance

funding: University of Botswana (Funds for Fieldwork and Travel), University of Florida (Adaptive Management: Water, Wetlands and Watersheds program funded by the National Science Foundation), Biokavango Project (Global EnvironmentFacility), JRS Biodiversity Foundation (Reformatting database to DC standards)

\section{Technical and administrative specifications}

$\begin{array}{ll}\text { data format: } & \text { txt } \\ \text { others/details: } & \text { DwC-A } \\ \text { operating system: } & \text { Linux } \\ \text { others/details: } & \text { Ubuntu } \\ \text { data language: } & \text { English } \\ \text { current access level: } & \text { web (public) } \\ \text { web address: } & \end{array}$

http://www.monitoringdata.ub.bw/ipt/resource?r=herbaceous floodplain vegetation mmh2007\&amp;v=1.0

\begin{tabular}{|c|c|}
\hline others/details: & https://www.gbif.org/dataset/602b5978-0777-41d7-8c9f-44f459b0f8ef \\
\hline currently available through $\underline{\mathrm{GBIF}}$ : & yes \\
\hline exchange planned: & no \\
\hline data in data repository: & yes \\
\hline specify repository: & http://www.monitoringdata.ub.bw/ipt \\
\hline
\end{tabular}

Do you plan to publish the data on the Freshwater Biodiversity Data Portal:

$\begin{array}{ll}\text { update level: } & \text { completed } \\ \text { documentation: } & \\ \text { type: } & \text { internal description } \\ \text { language: } & \text { English }\end{array}$

\section{contact details:}

metadata contact person:

first, last name:

phone:

email:

institution:

address:

postal code, city:

province, state:

country

web address:

technical contact person:

first, last name:

phone: no

English

Michael Murray-Hudson

+267 6817232

mmurray-hudson@ub.ac.bw

University of Botswana Okavango Research Institute

Private Bag 285

00000 Maun

North-West District

Botswana

https://www.ori.ub.bw/

Kaelo Makati

+2676817256 
email:

scientific contact person:

first, last name:

phone:

email: makatik@ub.ac.bw

Michael Murray-Hudson

$+2676817232$

mmurray-hudson@ub.ac.bw

\section{Intellectual property rights and citation}

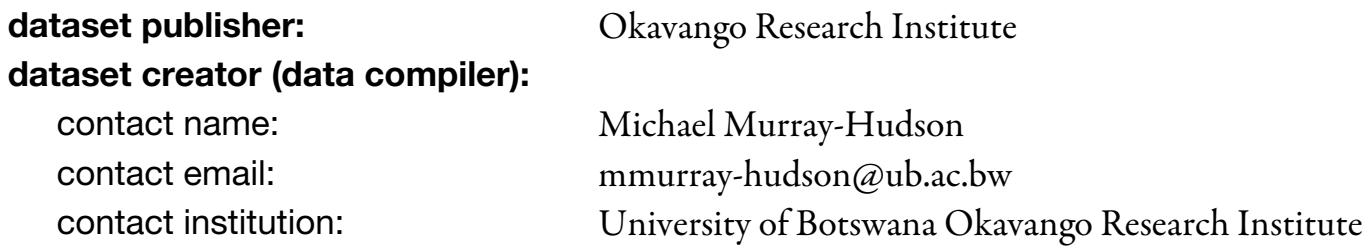

The dataset is publicly available (data portal, data archive) and can be used without restrictions, but dataset creator/data contributors must be informed prior to publication. Data must be acknowledged and cited correctly.

\section{data contributor/owner 2:}

contact name:

contact email:

Frances Murray-Hudson

fmurray-hudson@ub.ac.bw

contact institute:

Peter Smith Herbarium, Okavango Research Institute

criteria for using this part of the dataset:

The dataset is publicly available (data portal, data archive) and can be used without restrictions, but dataset creator/data contributors must be informed prior to publication. Data must be acknowledged and cited correctly.

data contributor/owner 3:

contact name:

Wilfred Khaneguba

contact email: wkhaneguba@ub.ac.bw contact institute: University of Botswana Okavango Research Institute criteria for using this part of the dataset:

The dataset is publicly available (data portal, data archive) and can be used without restrictions, but dataset creator/data contributors must be informed prior to publication. Data must be acknowledged and cited correctly.

\section{citation of this dataset:}

author(s):

Makati, K., Murray-Hudson, M.

title and journal (name, number, pages):

Boro and Xudum Floodplain Vegetation Data 2007. Version 1.1. Okavango Research Institute. Sampling event dataset https://doi.org/10.15468/fooskp accessed via GBIF.org on 2019-09-06.

year: 2019

version: 1

doi: 


\section{citation of the metadata:}

author(s):

Murray-Hudson, M., Makati, K., Mosie, I. \& Wolski, P.

title and journal (name, number, pages):

Metadata for macrophyte data from the Boro-Xudum seasonal floodplains of the

Okavango Delta. Freshwater Metadata Journal 45: 1-8

year:

2019

doi:

https://doi.org/10.15504/fmj.2019.45

\section{dataset related references:}

reference 1:

author(s):

title:

year:

reference 2:

author(s):

title:

year:

doi:

reference 3:

author(s):

title:

year:

doi:

reference 4:

author(s):

title:

year:

doi:

reference 5:

author(s):

title:

year:

doi:

reference 6:

author(s):

title:

year:

doi:

Murray-Hudson, M.

Floodplain Vegetation Responses to Flood Regime in the Seasonal Okavango

Delta, Botswana. PhD Dissertation, University of Florida, Gainesville

2009

Murray-Hudson, M., Combs, F., Wolski, P., Brown, M.T.

A vegetation-based hierarchical classification for seasonally pulsed floodplains in the Okavango Delta, Botswana. African Journal of Aquatic Science 36:3,

223-234.

2011

https://doi.org/10.2989/16085914.2011.636904

Murray-Hudson, M., Wolski, P., Cassidy, L., Brown, M., Thito, K., Kashe, K., Mosimanyana, E.

Remote Sensing-derived hydroperiod as a predictor of floodplain vegetation composition. Wetlands Ecology and Management 23:4, 603-616.

2015

https://doi.org/10.1007/s11273-014-9340-z

Murray-Hudson, M., Wolski, P., Murray-Hudson, F., Brown, M.T., Kashe, K. Disaggregating Hydroperiod: Components of the Seasonal Flood Pulse as Drivers of Plant Species Distribution in Floodplains of a Tropical Wetland.

Wetlands 34:5, 927-942.

2014

https://doi.org/10.1007/s13157-014-0554-x

Murray-Hudson, M., Wolski, P., Brown, M.T., Davidson, T.

A suite of macrophyte species distribution models for investigating hydrology-driven spatial changes in a large flood-pulsed tropical wetland. South African Geographical Journal 101:2, 141-157

2019

https://doi.org/10.1080/03736245.2018.1541021

Arias, M.E., Wittmann, F., Parolin, P., Murray-Hudson, M., Cochrane, T.A. Interactions between flooding and upland disturbance drives species diversity in large river floodplains. Hydrobiologia 814:1, 5-17.

2018

https://doi.org/10.1007/s10750-016-2664-3 


\section{General data specifications}

regional coverage of the dataset: spatial extent of the dataset: regional continents:

Africa

spatial extent (bounding coordinates):

southernmost latitude $\left[^{\circ}\right]$ :

northernmost latitude $\left[^{\circ}\right]$ :

westernmost longitude $\left[{ }^{\circ}\right]$ :

easternmost longitude $\left[{ }^{\circ}\right]$ :

23.236

minimum altitude:

940 metres

maximum altitude:

970 metres

countries:

Africa: Botswana

comments:

Okavango Delta seasonal floodplains

world climatic regions according to Köppen:

Group B: dry (arid and semiarid) climates

freshwater ecoregions of the world (FEOW) according to WWF:

ecosystem type:

covered timeframe:
Africa: Okavango

wetlands

$2007-2007$

\section{Site specifications}

coordinate system/grid data: grid data available:

comments:

\section{ecosystem type classification:}

wetlands (classification according to GLWD):

wetland type

freshwater marsh, floodplain

wetland size

$$
50-100 \% \text { wetland }
$$

site coding:

site coding available:

number of digits:

example:

number of sites:

exact number of sites:

comments: yes, alphanumerical

25

MMH_BOB-1-01_20070417-01

$<100$

30

Samples are $1 \mathrm{sq}$ m quadrats. Sites had 1-5 transects; a minimum of 30 quadrats $20 \mathrm{~m}$ apart along transects at each site.

\section{Climate and environmental data}

climate related data: environmental data:

available parameters per site: no climate data available

no environmental data per catchment available

information on floodplain inundation duration data source: remote sensing-derived hydroperiod 
comments:

physico-chemical data:

stressors influencing the sites: reference sites available: altitude

data source: from GPS

hydrological regime/flow regime

data source: remote sensing-derived hydroperiod

mean depth

data source: measured at site on date of survey

Shallow, elongate floodplains, which are seasonally pulsed and carry very slow flow. Highly permeable sandy organic soils.

no physico-chemical data available

no stressor data available

no

from sampling,

Floodplain vegetation responses to flood regime in the seasonal Okavango Delta, Botswana

Data collected as part of research for a PhD.

macrophytes

organism group addressed:

$2007-2007$

no

no

season: winter

time series data:

a single survey campaign from mid-March to mid-July 2007

comments:

no

Field survey work was carried out over the rising flood, for four months between mid-March and mid-July 2007.

\section{taxonomic resolution:}

level:

species

percentage of species level data: 99

comments:

Individuals were identified to species level in the field as far as possible. Where not possible they were pressed as herbarium specimens and submitted to the Peter Smith Herbarium (PSUB) at the University of Botswana Okavango Research Institute for identification. Specific unidentified grass specimens of the sub-family Panicoideae were sent to the Royal Botanical Gardens, Kew, United Kingdom for identification.

\section{taxonomic coding:}

taxalist according to:

reference(s):

Germishuizen, G., Meyer, N.L. 2007. http://posa.sanbi.org.

Germishuizen, G., Meyer, N.L., 2007. Plants of Southern Africa: an online checklist: http://posa.sanbi.org. 
coding system:

example:

\section{sample specifications:}

type:

replicate samples:

number of samples:

specification of method(s) used for sampling and sorting:

no

1080
Cook, C.D.K., 2004. Aquatic and wetland plants of southern Africa: An identification manual for the stoneworts (Charophytina), liverworts

(Marchantiopsida), mosses (Bryopsida), quillworts (Lycopodiopsida), ferns (Polypodiopsida) and flowering plants (Magnoliopsida) which grow in water and wetlands of Namibia, Botswana, Swaziland, Lesotho and Republic of South Africa. Leiden: Backhuys.

Gibbs-Russell, G.E. et al., 1991. Grasses of southern Africa - an identification manual. Memoirs of the Botanical Survey of South Africa No. 58. National Botanic Gardens/Botanical Research Institute, Pretoria.

Clarke, N.V., Klaassen, E.S., 2001. Water Plants of Namibia - an identification manual. Occasional Contributions 2, National Botanical Research Institute, Windhoek, Namibia

first three letters of genus, first three letters of species, no separator Abihis: Abildgaardia hispidula

quantitative (abundance data)

- Step 1 involved the selection of random sites for vegetation sampling. This was based on historic hydroperiod - a flood frequency map derived from remote sensing which assigned a frequency to each pixel. The frequency map was stratified into 5 strata of approximately equal area, and in each stratum 6 sites were selected by randomising the pixel numbers.

- Step 2 involved doing surveys of the vegetation at each site by laying out transects orthogonal to the long axis of each floodplain, and enumerating plant species within 1 square metre quadrats at 20 metre intervals along these transects. Species-area plots from sampling carried out beforehand indicated that a minimum of 25 square metres should be sampled. A minimum of 30 quadrats was thus surveyed at each site. All species in each quadrat were recorded and their relative abundance estimated according to a modified Braun-Blanquet classification.

reference(s): Wolski, P., Murray-Hudson, M. 2006. Reconstruction of 1989-2005 inundation history in the Okavango Delta, Botswana from archival Landsat imagery,

Globwetland Symposium. Frascati, Italy. ESA-ESRIN.

Wolski, P., Murray-Hudson, M. 2005. Flooding dynamics in a large low-gradient alluvial fan, the Okavango Delta, Botswana, from analysis and interpretation of a 30-year hydrometric record. Hydrol. Earth Syst. Sci. J1 HESS 10:1, 127-137.

sample type (e.g. habitat specific samples, composite samples etc.):

Quadrats were sampled along transects which crossed the topographic gradients of each floodplain site. That is, they were designed to sample all microhabitats within each floodplain site.

specific sample location (e.g. littoral, profundal, transect, shoreline, hyporheic zone, etc.):

Multiple transects per site. 


\section{Other specifications}

GIS layers, shape files related to the dataset:

availability of photos:
$\begin{aligned} & \text { novilability of maps: } \\ & \text { quality control procedures: }\end{aligned}$
Were any quality control procedures applied to your dataset?
yes
quality control protocols and comments:
Relative abundance estimates were made by consensus of at least two field
surveyors, and a one-day calibration exercise was carried out at the beginning of
the field work to ensure consistency. Data entry was done by M.
Murray-Hudson, and F. Murray-Hudson into a custom-designed Microsoft
Access relational database; reading of field sheets and typing was done
alternately, and data were cross-checked with field sheets after all had been
transcribed.

\section{Acknowledgements}

Frances Murray-Hudson, Wilfred Khaneguba, Mark T. Brown, JRS Biodiversity Foundation

\section{References}

Arias, M.E., Wittmann, F., Parolin, P., Murray-Hudson, M., Cochrane, T.A., 2018. Interactions between flooding and upland disturbance drives species diversity in large river floodplains. Hydrobiologia 814:1, 5-17.

https://doi.org/10.1007/s10750-016-2664-3

Murray-Hudson, M., 2009. Floodplain Vegetation Responses to Flood Regime in the Seasonal Okavango Delta, Botswana. PhD Dissertation, University of Florida, Gainesville

Murray-Hudson, M., Combs, F., Wolski, P., Brown, M.T., 2011. A vegetation-based hierarchical classification for seasonally pulsed floodplains in the Okavango Delta, Botswana. African Journal of Aquatic Science 36:3, 223-234. https://doi.org/10.2989/16085914.2011.636904

Murray-Hudson, M., Wolski, P., Brown, M.T., Davidson, T., 2019. A suite of macrophyte species distribution models for investigating hydrology-driven spatial changes in a large flood-pulsed tropical wetland. South African Geographical Journal 101:2, 141-157 https://doi.org/10.1080/03736245.2018.1541021

Murray-Hudson, M., Wolski, P., Cassidy, L., Brown, M., Thito, K., Kashe, K., Mosimanyana, E., 2015. Remote Sensing-derived hydroperiod as a predictor of floodplain vegetation composition. Wetlands Ecology and Management 23:4, 603-616. https://doi.org/10.1007/s11273-014-9340-z

Murray-Hudson, M., Wolski, P., Murray-Hudson, F., Brown, M.T., Kashe, K., 2014. Disaggregating Hydroperiod: Components of the Seasonal Flood Pulse as Drivers of Plant Species Distribution in Floodplains of a Tropical Wetland. Wetlands 34:5, 927-942. https://doi.org/10.1007/s13157-014-0554-x 